\title{
SOCIAL COMMUNICATIONS
}

\section{Імерсивні комікси як новий вид інформаційного продукту}

\author{
Д. О. Бєлов \\ Київський національний університет культури і мистецтв, Київ, Україна \\ Corresponding author. E-mail: liverpool1892dallas2011@gmail.com
}

Paper received 22.05.20; Accepted for publication 12.06.20.

\section{https://doi.org/10.31174/SEND-HS2020-231VIII39-04}

\begin{abstract}
Анотація. Стаття присвячена розкриттю специфіки коміксів із «розширеною реальністю», обгрунтуванню перспективності використання імерсивних технологій для формування комікс-культури і розвитку коміксу як інформаційного продукту, аналізу технологій розширеної реальності в цілому та інтегрування з ними коміксів, дослідженню основних тенденцій створення і розвитку імерсивних коміксів, розгляду окремих видань, які вплинули на розвиток використання імерсивних технологій в коміксовій культурі.
\end{abstract}

Ключові слова: комікс, імерсивні технології, інформаційний продукт, розиирена реальність, імерсивні комікси.

Вступ. 90-ті роки ХХ століття стали початком нової ери в історії людства - ери Інтернету. Розвиток науки спричинив появу феномену, який за своїми наслідками співставний з винайденням друкарського верстату: ми є свідками пов'язаних 3 інтернет-технологіями змін революційного характеру в різних сферах суспільного життя трансформацій в системі управління, економіці, соціальній структурі суспільства, мистецтві, способах комунікації та сприйняття інформації. Змінюється сам простір і наші уявлення про нього: ідеться про появу феноменів віртуальної, доповненої та змішаної реальності імерсивних технологій, які «розширюють реальність».

Імерсивні технології широко застосовуються в різноманітних сферах суспільного буття - виробництві, науці, культурі. Технології розширеної реальності вплинули і на культуру коміксу, яка до останнього часу проявлялась, переважно, у вигляді фільмів, паперової продукції (книг, журналів, газет), іграшок, костюмованих фестивалів тощо. 3 розвитком інтернет-технологій та сучасних засобів комунікації комікс почав активно інтегруватися у віртуальне середовище, що актуалізує наукове осмислення ключових тенденцій цьогопроцесу.

Короткий огляд публікацій по темі. Як соціокомунікаційне явище і культурний продукт комікс привертав увагу таких науковців, як Д. Айдачич, Р. Бреннер (R. Brenner), П. Гревейт (P. Gravett), Т. Гронстін (Т. Groensteen), О. Гудошник, Д. Квіарі (J. Quearry), Д. Кipхгофф (J. Kirchoff), Н. Кон (N. Cohn), Н. Космацька, М. Кузнецова, Р. Петерсен (R. S. Petersen), Г. Почепцов, O. Сонін, С. Хлестова та ін., які, переважно, зосереджують увагу на його структурно-функціональних особливостях, комунікаційному потенціалі, історії виникнення, національній специфіці, цифровій адаптації тощо. Водночас на часі дослідити можливості розвитку коміксу 3 використанням технологій «розширеної реальності».

Мета статті - висвітлити становлення і розкрити специфіку коміксів із «розширеною реальністю», обгрунтувати перспективність використання імерсивних технологій для формування комікс-культури і розвитку коміксу як інформаційного продукту.

Матеріали і методи. Для реалізації мети було використано термінологічний метод для з'ясування понять віртуальна, доповнена, змішана реальність та імерсивні технології, метод включеного спостереження та порівняльний для виявлення переваг сприйняття читачем коміксів, що супроводжуються технологією доповненої реальності, метод аналізу контенту, який виявився необхідним під час роботи 3 інтернет-ресурсами, пов'язаними з виробництвом і просуванням комікс-продукції.

Результати та їх обговорення. Для початку визначимось із термінами.

Віртуальна реальність (virtual reality - VR) - це комп'ютерне моделювання простору, який може бути випробуваним $з$ використанням спеціального електронного програмного забезпечення. Термін «віртуальна реальність» був популяризований Д. Ланьє у 80-х рр. XX ст.

В. Климнюк визначає VR як різновид комп'ютерного моделювання, який «дозволяє користувачу заглибитися у штучний світ і безпосередньо діяти в ньому за допомогою спеціальних сенсорних пристроїв, які зв'язують його з аудіовізуальними ефектами» [2, с. 207]. Характерною ознакою VR, на яку звертає увагу Ю. Трач, є ефект присутності і зміна зображень в режимі реального часу [4, с. 309-310]. Р. Павлюк, своєю чергою, підкреслює важливість ефекту присутності для визначення віртуальної реальності і говорить про можливість не просто дії, а взаємодії з представленими у віртуальній реальності об'єктами, «включаючи зокрема нові способи взаємодії: зміна форми об'єкта, вільне пересування між мікрота макрорівнями простору, пересування самого простору тощо» [3].

Доповнена реальність (augmentedreality - AR) - це доповнення реального світу цифровими і графічними даними в режимі реального часу з використанням програмних засобів [1]. AR розширює сприйняття людиною реального світу через доповнення реальних об'єктів пов'язаною з ними цифровою інформацією. AR не створює нового середовища замість реального, як у випадку $3 \mathrm{VR}$, але доповнює його. Винайдення терміну доповненої реальності (1990р.) належить Т. Коделлу, колишньому досліднику компанії «Boeing», а перша функціональна AR-система була запропонована Л. Розенбергом у 1992 р. Вже у 1997 р. відбувся перший Міжнародний семінар, присвячений доповненій реальності International Workshopon Augmented Reality (IWAR) [1].

Змішана реальність (mixedreality - MR) - це злиття реального та віртуального просторів (доповнена реальність і доповнена віртуальність) для створення нових середовищ, де фізичні об'єкти реального простору i цифрові об'єкти віртуального середовища співіснують і взаємодіють в режимі реального часу. Ключова характеристика змішаної реальності - здатність віртуального 
компоненту реагувати на зміни реального.

Для узагальненого позначення всіх цих технологій використовується термін «розширена реальність» або імерсивні технології.

На сьогодні відбувається інтеграція коміксів 3 AR i VR технологіями. Комікси 3 доповненою реальністю зовні виглядають, як звичайні книги, які користувач може читати, гортаючи сторінки. Проте при наведенні на сторінки камери смартфону або планшету із завантаженим відповідним застосунком контент коміксу починає «оживати» - персонажі набувають об'єму і починають рухатись, змінюється їх колір, навколо них з'являються додаткові деталі, які доповнюють або уточнюють сюжет та посилюють емоційне сприйняття. На сторінці можна побачити рухи персонажів, сцени битв між головним героєм та злодієм або ж фонові зображення, що імітують, наприклад, коливання хмар, дощу чи снігу, отримати переклад незрозумілої мови чужинців, почути коментарі персонажів. Комікс із доповненою реальністю за рахунок багатошарових графічних файлів отримує третій вимір і третій компонент оповідання - поряд із зображенням і текстом як основними компонентами коміксу з'являсться технологія, без якої частина змісту втрачається. $3 \mathrm{AR}$ історія стає більш реалістичною, межа між нею і читачем стирається. Тісний зв'язок із читачем і здатність книжки якнайточніше виразити задум авторів є одними 3 основних переваг коміксів із вмістом для AR.

Першим застосунком для візуалізації коміксів став MarvelAR App. Це мобільний застосунок, розроблений компанією Марвел з ARAurasma. Розробка застосунку дала змогу користувачам сканувати певні комікси Марвел, щоб розкрити ексклюзивний вміст, такий як відео, коментарі та ін. [11].

Marvel AR App було представлено на фестивалі Southby Southwest (SXSW) («На Південь через Південний Захід») 11 березня 2012 р. Застосунок було випущено для завантаження в GooglePlay та iOS AppStore. Перший комікс, сумісний із програмою, був Avengersvs. XMen \#1. Генеральний менеджер Marvel Digital Media Group П. Філліпс вважає, що комікси із застосуванням подібних технологій - це «найбільша історія, яку колинебудь розповідали, вони дають змогу читачам глибше зануритись в комікси Marvel» [11].

3 того часумайже кожна нова серія Marvel доповнюється бонусним вмістом для застосунку AR. Деякі з цих серій маливмістдля зчитування застосунком лише протягом перших кількох випусків, а інші містили контент для AR протягом повного тиражу.

Поряд 3 коміксами Марвел одним 3 перших коміксів 3 використанням імерсивних технологій вважається «Modern Polaxis» C. Кемпбела. Цей комікс поєднується iз застосунком для iPhone та iPad, він містить 50 сторінок аудіовізуального контенту. Героєм коміксу єхлопець-мандрівник у часі, який веде журнал (у вигляді якого і створено, власне, комікс) та записує в нього свої думки, разом $з$ тим ховаючи в ньому шар, який дозволяє розширити реальність та відкрити різні світи. Доповнена реальність «Сучасного Полаксису» дає читачеві багато поглядів на історію, наближуючи сприйняття тексту до філософського розуміння. Тут, так, як і в реальному житті, $є$ те, що ми бачимо «на поверхні», і є прихований зміст. Книгу можна читати, як звичайну, без використанняAR, проте в цьому випадку читач отримає лише половину історії: кожна сторінка містить елементи для доповненої реальності, і частина цього матеріалу відкриває зовсім інший сюжет, відмінний від того, який надрукований на сторінці. Трапляються моменти, коли доповнена реальність не тільки додає більше деталей до того, що написано в книзі, але й змінює сюжет, змушуючи читача переосмислювати прочитане раніше.

Для втілення свого проекту С. Кемпбел опублікував ідею коміксу з AR на платформі «Кікстартер» і зібрав більше 10 тис. дол. на іiі реалізацію, що найкраще засвідчило актуальність використання в коміксах технологій «розширеної реальності». Після публікації, його комікс разом із застосунком став популярним у всьому світі, що вплинуло на інших ініціатив звиробництва інтерактивних коміксів.

Серед таких ініціатив - створення Д. Корі, К. Феноліо, Д. Ланфара та К. д'Ерікоу співробітництві з компанією Blippar, яка спеціалізується на технології AR, коміксів із технологією доповненої реальності «Bloodworth» про агента ФБР Бренду Бладворт, яка розкриває злочини, занурюючись у спогади інших [5]; проект Р. Шилдса «Neon Wasteland» [6], створений у стилі кіберпанк, де кожна панель «оживає», що перетворює сторінки книжки в інтерактивний анімований сюжет; серія фантастичних коміксів AR «Fasterthan Light» від Б. Хаберліна [8], в яких до кожного випуску було додано голосовий журнал капітана космічного корабля, що дало змогу дізнатися його особисте сприйняття історії; серія коміксів про п'ять родин чарівників «The Magic Order» [14], написана М.Мілларом та проілюстрована О.Койпелем (його попередні роботи - «Дивовижна людина-павук», «Месники» , «Тор» та «Люди Х») тощо.

Для того, щоб зробити знайомство 3 коміксами $3 \mathrm{AR}$ зручнішим, компанії - виробники коміксів починають залучати до співпраці виробників гарнітури AR. Зокрема, компанія Madefire, яка займається випуском анімованих версій коміксів розпочала співробітництво з виробником AR-окулярі в Magic Leap. Окуляри створюють ефект занурення, що виведе враження від читання коміксу на новий рівень.

Проте найбільше занурення можливе 3 технологієюVR. На думку авторів Марвел, «VR-комікси створюють точку відліку для поп-культури майбутнього. Це більше ніж книга. Це цілий парк розваг» [7].

Першими коміксами VR стала серія «Magnetique», запущена 2016 р. компанією Oniride для Gear VR (через Oculus Store), [10]. У Magnetique розповідається про пригоди молодого ляльковода, який відправився у вигадану країну Сіань. Це новаторський продукт, у якому кожна панель може бути випробувана у форматі 360 градусів. Самі сторінки перегортаються як зазвичай, але все, що на них відбувається, відбувається навколо читача у форматі 360 градусів. Мовленневі бульбашки збільшуються, коли читач дивиться на них, а додані аудіо ефекти посилюють ефект занурення. В результаті виходить продукт на перетині звичайного коміксу і цифрової графічної новели AR.

У 2018 р. компанією Square Enix було презентовано VR адаптацію для Oculusi HTC Vive успішної японської манги «Tales of Wedding Rings». Гаслом проекту стало «Крок всередину розповіді» («Stepinsidethestory»). Як зазначив керівник проекту К. Су, створений продукт дає змогу читачеві «потрапити всередину» сторінки і зануритись у вигаданий світ [12]. Це суміш фільму, віртуа- 
льної реальності і анімованого коміксу. У поточній версії коміксу присутня і аудіо складова. Розмови героїв озвучені японською мовою і супроводжуються англійськими субтитрами. Новацією Square Enix стали «плаваючі панелі», які сама компанія називає «живими»(«Live Panels»).У чітко виражених панелях об'єкти представляються тривимірними. При цьому читач може пересуватися в різних напрямках, в яких знаходиться та чи інша панель, і може сам визначати, яку саме сюжетну лінію він хоче читати-дивитись-переживати [13].

Поряд з адаптаціями до «розширеної реальності» популярних коміксів 2017 р. компанія Spiraloid Workshop оголосила про випуск першого голографічного роману (імерсивного коміксу) (VR) на основі оригінального сценарію «Nanite Fulcrum» для Oculus Rift i VR Gear та оптимізованого для Touch. На відміну від попередніх прикладів, прочитати роман можна лише у форматі 3D. Один з авторів продукту Б. Рейтт зазначив: «Ми винаходимо графічний роман у VR. Поєднання найкращого в коміксах, іграх, фільмах та культурі співтворення трансформується у захоплюючий оповідальний досвід, який дає змогу нашим шанувальникам та партнерам читати, грати, дивитися та навіть творити поруч із нами»[9]. Продукт має «сторінки», які можна гортати,представляє персонажів, з якими можна зустрітися, містить загадки між панелями, які можна розгадувати та панелі для входу та дослідження. Такий імерсивний комікс не лише сам стає нелінійним і багатошаровим, а й створює умови для варіативності поведінки читача, який завдяки своїй фантазії і взаємодії з контентом здатен емоційно збагатити і пожвавити вигадані світи і розсунути їх межі.

Висновки. Отже, впровадження технологій «розширеної реальності» у виробництво коміксів стало новим етапом у розвитку цього виду інформаційного продукту і призвело до появи інноваційного формату цих видань імерсивних коміксів, характерною особливістю яких $є$ нелінійність і ефект занурення. Тепер під час взаємодії читача $з$ коміксом відбувається не лише процес читанняспоглядання, але й відчуття-переживання. Читач може не лише слідувати заданій авторами коміксу траєкторії оповідання, а й вибудовувати власну траєкторію. В імерсивних коміксах поряд з традиційними компонентами зображенням і текстом - одну з ключових ролей відіграє імерсивна технологія, без якої частина змісту втрачається. Особливістю виробництва імерсивних коміксів $€$ співпраця не лише письменників і ілюстраторів, авторів і видавців, а і їх усіх 3-виробниками програмного контенту, що перетворює виробництво кожної серії таких коміксів на масштабні проекти. Разом із тим збільшення кількості таких проектів і готовність спільноти і провідних компаній - виробників контенту вкладати в них кошти свідчить про перспективність такого виду продукту і його упевнене майбутнє.

\section{ЛITЕРАТУРА}

1. Дополненная реальность (или Augmented Reality, AR). iGudvin. 2020. URL: https://igudvin.ru/stati/dopolnennayarealnost-ili-augmented-reality-ar (Дата обращения: 20.01.2020).

2. Климнюк В. Є. Віртуальна реальність в освітньому процесі. Збірник наукових праць Харківського національного університету Повітряних Сил. 2018. Т. 2. № 56. С. 207-212.

3. Павлюк Р. О. Концепції дослідження теорії віртуальності у педагогічних науках. Освітологічний дискурс: ел. фахове видання КУ імені Бориса Грінченка. 2014. № 2. URL: https://cutt.ly/AyjpR20 (Дата звернення: 20.01.2020).

4. Tрач Ю. VR-технології як метод і засіб навчання. Освітологічний дискурс: ел. фахове видання КУ імені Бориса Грінченка. 2017. № 3-4 (18-19). С. 309-322.

5. Comic Books Cometo Life with Augmented Reality. Blippar. 2016. March 21. https://cutt.ly/UyjpHjh (accessed: 03.05.2020).

6. Comic meets cartoon. Neonwastelandgame. URL: https://www.neonwastelandgame.com/ (accessed: 03.05.2020).

7. D. D'Orazio. Marvel reveals augmented reality for comic books, new 'Infinite' digital comics. 2012. March 11. URL: https://cutt.ly/eyjpKeD (accessed: 03.05.2020).

8. Faster https://imagecomics.com/comics/series/faster-than-light (accessed: 03.05.2020).

9. From Acclaimed Creator Bay Raitt Comes TheSpiraloid Workshop Co. Businesswire. URL: https://cutt.ly/ZyjoVLW (accessed: 03.05.2020).

10. Magnetique is the first VR Comic for Virtual Reality Headsets. Oniride. URL: http://www.oniride.com/magnetiquevr. (accessed: 03.05.2020).

11. Marvel AR. FANDOM. n. d. URL: https://marvel.fandom.com/wiki/Marvel_AR (accessed: 03.05.2020).

12. Tales of Wedding Rings VR. Oculus. URL: https://cutt.ly/FyjyVmH. (accessed: 03.05.2020).

13. Tales of Wedding Rings VR. Store.steampowered. URL: https://cutt.ly/ayjyMqy/). (accessed: 03.05.2020).

14. Trenholm R. Netflix's first comic The Magic Order conjures Facebook AR trickery. 2018. June 13. URL: https://cutt.ly/tyjpJcx/ (accessed: 03.05.2020).

\section{REFERENCES}

1. Augmented reality (or Augmented Reality, AR). iGudvin. 2020. URL: $\quad$ https://igudvin.ru/stati/dopolnennaya-realnost-iliaugmented-reality-ar (Date of access: 01.20.2020).

2. Klimnyuk, V.E. Virtual reality in the educational process. Collection of scientific works of Kharkiv National University of the Air Force. 2018. T. 2. № 56. S. 207-212.

3. Pavlyuk, R.O. Concepts of research of the theory of virtuality in

Immersive comics as a new kind of information product

D. O. Belov

Abstract. The article is devoted to the specifics of comics with "augmented reality", substantiation of the prospects of using immersive technologies for the formation of comic culture and comic book development as an information product, analysis of augmented reality technologies in general and integration with them comics, study of major trends in creation and development of immersive comics. individual publications that have influenced the development of the use of immersive technologies in comic culture.

Keywords: comics, immersive technologies, information product, augmented reality, immersive comics. 